\title{
PROSES FORMULASI EMULSI FIKOSIANIN SEBAGAI ANTIOKSIDAN DENGAN VIRGIN COCONUT OIL (VCO) SEBAGAI FASE MINYAK
}

\author{
(Formulation Process of Emulsion of Phycocyanin as Antioxidant with Virgin Coconut Oil (VCO) \\ as Oil Phase)
}

\author{
Siti Agustina, Novi Nur Aidha, Eva Oktarina, Ira Setiawati \\ Badan Penelitian dan Pengembangan Industri, Kementerian Perindustrian, Jl. Jendral Gatot Subroto Kavling \\ 52-53 Jakarta, 12950, Indonesia \\ e-mail: tinaratujaya@yahoo.com
}

Diterima 03 Juli 2020, Revisi akhir 25 Nopember 2020, Disetujui 27 Nopember 2020

\begin{abstract}
ABSTRAK. Indonesia merupakan wilayah yang berpotensi untuk perkembangan budidaya mikroalga, salah satu diantaranya adalah spirulina yang mengandung antioksidan fikosianin. Antioksidan fikosianin digunakan pada industri kosmetik, farmasi dan makanan. Pada diverifikasi produk, antioksidan fikosianin dapat dimanfaatkan dalam bentuk emulsi. Tujuan penelitian ini adalah melakukan dan mengamati proses formulasi emulsi fikosianin sebagai antioksidan dengan VCO sebagai fase minyak, menggunakan metode homogenisasi dengan tekanan tinggi (high pressure homogenation). Pada penelitian ini, jenis emulsi yang dibuat adalah minyak dalam air (oil in water, o/w) dengan fase minyak berupa VCO dan fase air yaitu larutan fikosianin. Emulsi yang dibuat terdiri dari 9 formula menggunakan Carboxyl Methyl Cellulose (CMC) sebagai emulsifier. Rancangan penelitian menggunakan software Design Expert ${ }^{\circledR} 7.0$ dengan metode D-Optimal Design, yang merupakan salah satu metode permukaan tanggap, untuk mendapatkan formula emulsi yang terbaik bedasarkan karakteristiknya. Karakteristik yang diamati adalah pH, kestabilan emulsi, viskositas, kadar antioksidan dan aktivitas antioksidannya. Hasil formula terbaik ditunjukkan pada konsentrasi fikosianin 131,25 g dan VCO 31,25 $g$ dengan pH 4,64; viskositas sebesar 113 cps, kadar antioksidan sebesar 0,07 mg vitamin C/g dan aktivitas antioksidan $I_{50} \quad 838,80 \mathrm{mg} / \mathrm{ml}$. Berdasarkan hasil tersebut, emulsi fikosianin sebagai antioksidan dengan VCO dapat diaplikasikan untuk industri kosmetik, farmasi dan makanan.
\end{abstract}

Kata kunci: antioksidan, emulsi, fikosianin, VCO, mikroalga

\begin{abstract}
Indonesia is a potential area for microalgae growth, including spirulina microalga which is rich in phycocyanin antioxidants. This antioxidant utilized by cosmetics, pharmaceutical and food industries. Product diversifications of phycocyanin as antioxidant can be made in emulsion form. The purpose of this study is to observe the emulsion formulation process of phycocyanin, as an antioxidant, with VCO as the oil phase using High Pressure Homogenation method. In this study, the type of emulsion was oil in water $(o / w)$, by VCO as oil phase and phycocyanin as water phase. The emulsions were consisted of 9 (nine) formulations, by using Carboxyl Methyl Cellulose (CMC) as emulsifier. The design research was used Design Expert ${ }^{\circledR} 7.0$ software with D-Optimal Design method, which was one of the response surface methods, to obtain the best emulsion formulation based on the characteristics. The characteristics being observed were pH, stability of emulsion, viscosity, antioxidant levels and antioxidant activity. The best formulation was at the concentration of phycocyanin $131.25 \mathrm{~g}$ and VCO $31.25 \mathrm{~g}$ with $\mathrm{pH} 4.64$ and viscosity $113 \mathrm{cps}$, antioxidant levels $0.07 \mathrm{mg}$ vitamin $\mathrm{C} / \mathrm{g}$ sample and antioxidant activity $\left(I C_{50}\right) 838,80 \mathrm{mg} / \mathrm{ml}$. Based on this result, the antioxidant emulsions can be applied to the cosmetics, pharmaceutical, and food industries.
\end{abstract}

Keywords: antioxidant, emulsion, phycocyanin, VCO, microalgae

\section{PENDAHULUAN}

Fikosianin merupakan pigmen alami berwarna biru yang terkandung di dalam alga biru kehijauan (Sianobakteri) seperti Spirulina atau Arthospira (Furuki et al., 2003). Fikosianin diekstrak dari Sianobakteri dengan pemecahan 
dinding sel dan ekstraksi fikobiliprotein yang larut air. Fikosianin adalah pigmen fotosintetis yang menyerap sinar dengan panjang gelombang sekitar $620 \mathrm{~nm}$ dan memancarkan sinar pada $640 \mathrm{~nm}$. Pigmen ini digunakan secara umum pada beberapa bidang seperti makanan, kosmetik, bioteknologi dan kesehatan (Eriksen, 2008; Agustina et al., 2018; Chaiklahan et al., 2012). Penggunaannya yaitu sebagai antioksidan, antiinflamasi, antiplatelet, antikanker, antijamur, antivirus, neuroprotective dan hepatoprotective.

Sifat fikosianin sebagai antioksidan adalah dengan melindungi sel dari oksidasi dan menghambat produksi spesies oksigen reaktif (reactive oxygen species, ROS). Apabila jumlah radikal bebas dan ROS dalam tubuh melebihi kemampuan antioksidan endogen, maka tubuh memerlukan asupan antioksidan, salah satunya adalah fikosianin. Sifat antioksidan yang dimiliki fikosianin juga berperan penting dalam menekan berbagai penyakit degeneratif (Dejsungkranont $e t$ al., 2017). Fikosianin mengandung asam amino, oleh karena itu stabilitas fikosianin dipengaruhi oleh cahaya, suhu, $\mathrm{pH}$ dan kadar protein yang dapat mengakibatkan denaturasi, presipitasi serta perubahan warna (Chaiklahan et al., 2012). Salah satu cara untuk menjaga kestabilan fikosianin adalah dengan mengubahnya dalam bentuk emulsi minyak dalam air.

Emulsi adalah sistem termodinamis tidak stabil yang mengandung dua fase tidak larut. Bentuk ini akan distabilkan oleh pengemulsi. Emulsi minyak dalam air terdiri dari dua fase, yaitu fase minyak yang didispersikan dalam fase air (Silva et al., 2012). Emulsi dapat diproduksi dengan beberapa metode seperti homogenisasi dengan tekanan tinggi, ultrasonik, pengadukan dengan kecepatan tinggi (high speed mixer), colloidal mill, microfluidization dan menggunakan membran. Homogenisasi tekanan tinggi dapat mengurangi ukuran droplet ke minimum $0,1 \mu \mathrm{m}$ dan dapat meningkatkan umur simpan emulsi dengan mengurangi laju creaming emulsi (Juttulapa et al., 2017; McClements, 2005). Homogenasasi dengan tekanan tinggi adalah proses yang paling sering digunakan untuk memproduksi emulsi karena proses kontinyu tanpa menggunakan panas dan emulsi yang dihasilkan memiliki tekstur yang halus dengan sifat dan karakteristik yang baik serta stabilitas yang lebih baik (Kuhn \& Cunha, 2012; McClements, 2005).

Emulsi nano Spirulina telah diteliti untuk penggunaannya dalam drug delivery system (Hemalatha et al., 2015; Teuling et al., 2019;
Wang et al., 2018). Emulsi fikosianin sebagai pewarna alami yang mengandung antioksidan telah dilakukan oleh Batista et al. (2006). Hasil penelitian menunjukkan bahwa fikosianin dapat dipertahankan dalam bentuk emulsi. Paten emulsi fikosianin air-minyak-air sebagai pewarna makanan juga telah diklaim oleh Mason and Bonnet (2011), dengan nomor paten EP2635137A1. Fikosianin dan Virgin Coconut Oil (VCO) sangat sensitif terhadap panas, oleh karena itu pada penelitian ini proses emulsi menggunakan homogenisasi dengan tekanan tinggi. Campuran emulsi diperlakukan dengan tekanan sangat tinggi dan dipompa melalui katup. Tegangan geser yang sangat tinggi menyebabkan pembentukan droplet emulsi (Silva et al., 2012).

Pada penelitian ini, fase minyak yang digunakan adalah VCO. Sebagai fase minyak, VCO terbentuk dari endosperma buah kelapa yang diproses pada suhu rendah. VCO dapat dibuat dengan beberapa proses seperti pemanasan bertahap, penghilangan minyak dan fermentasi (Anwar \& Salima, 2016). VCO kaya akan rantai asam lemak sedang, yang dapat mengurangi kolesterol dalam darah dan meningkatkan metabolisme tubuh. Zat polifenolik yang dikandung dapat mengurangi spesies oksigen reaktif (ROS), menghambat oksidasi lipoprotein densitas rendah dan menunjukkan aktivitas antiatherogenic (Nevin \& Rajamohan, 2004). VCO banyak digunakan sebagai makanan fungsional maupun sebagai suplemen untuk menjaga ketahanan tubuh. Rasa minyak dan sedikit asam dari VCO menyebabkan rasa VCO kurang dapat diterima konsumen (Villarino et al., 2007). VCO dapat diolah menjadi bentuk emulsi, sebagai salah satu produk olahan tanpa mengurangi nilai fungsionalnya. Pada penelitian ini, VCO selain memiliki nilai fungsional untuk kesehatan, juga memiliki fungsi untuk menjaga stabilitas fikosianin. Hal ini didukung oleh penelitian sebelumnya oleh Suhendra et al. (2014) yang membuat emulsi VCO untuk menjaga stabilitas fucoxanthin.

Zat pengemulsi yang digunakan pada penelitian ini adalah carboxymethyl cellulose (CMC). CMC adalah rantai panjang polimer dari selulosa yang larut dalam air dingin maupun panas. CMC saat ini digunakan sebagai bahan aditif pada produk makanan dan aman untuk dikonsumsi (Nurhayati \& Budiyanto, 2016). CMC adalah hidrokoloid dengan aktifitas permukaan yang bertindak sebagai pengemulsi pada emulsi minyak 
dalam air, sehingga umum digunakan pada emulsi minyak-air (Arancibia et al., 2016).

Tujuan dari penelitian ini adalah melakukan dan mengamati proses formulasi emulsi fikosianin sebagai antioksidan dengan VCO sebagai fase minyak serta CMC sebagai zat pengemulsi menggunakan metode homogenisasi dengan tekanan tinggi (High Pressure Homogenation). Penelitian ini dilakukan dengan menggunakan metode rancangan penelitian permukaan tanggap (Response Surface Methodology, RSM). Metode permukaan tanggap adalah suatu metode statistika dan matematika yang digunakan dalam pemodelan dan analisis untuk mengembangkan, meningkatkan, dan mengetahui kondisi proses yang optimal (Agustina et al., 2019). D-Optimal Design merupakan salah satu metode pada RSM yang dapat digunakan untuk menentukan formulasi emulsi terbaik bedasarkan karakterisitknya seperti $\mathrm{pH}$, viskositas, kestabilan emulsi dan kapasitas antioksidan. Kebaruan penelitian ini dibandingkan dengan penelitian sebelumnya adalah proses formulasi emulsi dari fikosianin sebagai antioksidan dan VCO dengan proses homogenisasi tekanan tinggi dan penggunaan metode RSM. Variabel yang digunakan pada RSM adalah 9 variabel perbandingan berat antara fikosianin dengan VCO. Sehingga, didapatkan formula emulsi fikosianin sebagai antioksidan dengan VCO yang dapat digunakan pada industri makanan, kosmetik dan farmasi.

\section{METODE PENELITIAN}

Bahan-bahan yang digunakan antara lain Spirulina yang diperoleh dari PT. Neo Alga Indonesia Makmur, VCO (Kautsar Herbal Indonesia), CMC dari Bratachem, akuades, 2,2diphenyl-1-picrylhydrazyl (DPPH) (Sigma), Butylated hydroxytoluene (BHT) (Sigma) dan asam askorbat (Merck). Alat yang digunakan untuk memproduksi fikosianin adalah homogenizer (Miyamoto Riken) dan sentrifuse (Kokusan), High Pressure Homogenizer (KGC Sciencetific) dengan tekanan 30 Mpa selama 10 menit untuk produksi emulsi antioksidan. Peralatan analisa menggunakan pH-meter (Thermo Sciencetific), viskometer (Brookfield), spektrofotometer (Shimadzu), pemanas berpengaduk (IKA) dan timbangan analisis (Metler Toledo).

\section{Ekstraksi Fikosianin}

Proses ekstraksi fikosianin telah didapatkan proses yang optimum pada penelitian sebelumnya, yaitu dilakukan dengan melarutkan Spirulina dalam akuades dengan konsentrasi $1 \%$ w/v. Ekstraksi dilakukan dengan metode maserasi menggunakan kecepatan pengadukan $190 \mathrm{rpm}$ selama 1 jam. Selanjutnya dilakukan pemisahan ekstrak fikosianin menggunakan alat sentrifugasi dengan kecepatan $2500 \mathrm{rpm}$ selama 30 menit (Agustina et al., 2018).

\section{Formulasi Emulsi VCO}

Proses formulasi emulsi dilakukan menggunakan metode High Pressure Homogenization (HPH), dengan mencampur larutan fikosianin dan CMC. Larutan tersebut diaduk hingga homogen selama beberapa menit sampai CMC larut sempurna. Setelah itu ditambahkan VCO secara perlahan dan diaduk hingga tercampur. Larutan campuran selanjutnya dimasukkan ke dalam alat homogenizer bertekanan dengan tekanan 30 MPA selama 10 menit (Hangganararas, 2014). Pada proses formulasi emulsi digunakan fikosianin dari Spirulina sp. sebagai fase air sekaligus sumber antioksidan. VCO digunakan sebagai fase minyak dan CMC sebagai zat pengemulsi. Sirup gula ditambahkan sebagai sumber fruktosa.

Data formulasi emulsi menggunakan metode permukaan tanggap yaitu Design Expert 7.0 dengan D-Optimal Design yang salah satu metode untuk mendapatkan formula emulsi yang terbaik bedasarkan karakteristiknya. Metode ini menggunakan 2 faktor yaitu berat fikosianin dan VCO serta 5 respon/variabel yang diamati yaitu $\mathrm{pH}$, kestabilan emulsi, viskositas, kadar antioksidan dan aktivitas antioksidan yang dapat dilihat pada Tabel 1. Berdasar data RSM tersebut, diperoleh formula fikosianin dan VCO yang dapat dilihat pada Tabel 2.

\section{Tabel 1. Data RSM}

\begin{tabular}{|c|c|c|c|c|}
\hline Faktor & Unit & $\begin{array}{c}\text { Batas } \\
\text { atas }\end{array}$ & $\begin{array}{c}\text { Batas } \\
\text { bawah }\end{array}$ & Respon \\
\hline Fikosianin & gram & 150 & 131,25 & $\begin{array}{c}\mathrm{pH} \\
\text { kestabilan }\end{array}$ \\
\hline $\mathrm{VCO}$ & gram & 50 & 12,5 & $\begin{array}{c}\text { emulsi, } \\
\text { viskositas, } \\
\text { kadar } \\
\text { antioksidan, } \\
\text { aktivitas } \\
\text { antioksidan }\end{array}$ \\
\hline
\end{tabular}


Tabel 2. Formulasi emulsi VCO dan fikosianin sebagai antioksidan

\begin{tabular}{lccccccccc}
\hline \multirow{2}{*}{ Komponen } & \multicolumn{10}{c}{ Formulasi } \\
\cline { 2 - 10 } & F1 & F2 & F3 & F4 & F5 & F6 & F7 & F8 & F9 \\
\hline PC & 140,63 & 131,25 & 150 & 131,25 & 150 & 140,63 & 140,63 & 131,25 & 150 \\
VCikosianin) & 12,5 & 50 & 12,5 & 31,25 & 31,25 & 31,25 & 50 & 12,5 & 50 \\
(Virgin Coconut Oil) & 1 & 1 & 1 & 1 & 1 & 1 & 1 & 1 & 1 \\
CMC & 5 & 5 & 5 & 5 & 5 & 5 & 5 & 5 & 5 \\
(Carboxymethyl Cellulose) & Sirup & & & & & & & &
\end{tabular}

\section{Aktivitas Antioksidan}

Prosedur analisis kapasitas antioksidan menggunakan metode Ascorbic acid Equivalent Antioxidant Capacity (AEAC) dengan 2,2diphenyl-1-picrylhydrazyl (DPPH) sebagai sumber radikal bebas. Hasil emulsi dicampurkan dengan larutan metanol, dibuat menjadi suatu rentang konsentrasi, direaksikan dengan DPPH dan disimpan pada tempat yang gelap selama 120 menit. Setelah itu, larutan diukur absorbansinya pada panjang gelombang $517 \mathrm{~nm}$ dengan menggunakan blanko akuades dan asam askorbat sebagai pembanding (Velde et al. 2013). Persen inhibisi diukur dengan rumus, yang selanjutnya digunakan untuk menentukan $\mathrm{IC}_{50}$. Pada nilai $\mathrm{IC}_{50}$, rentang konsentrasi emulsi sebagai absis (x) dan persen inhibisi sebagai ordinat (y) maka dengan regresi linier akan diperoleh persamaan garis. Nilai $\mathrm{IC}_{50}$ ditentukan berdasarkan konsentrasi larutan emulsi saat persen inhibisi 50\% (Blois 1958). Nilai AEAC menunjukkan kemampuan atau kapasitas emulsi untuk menekan DPPH sebagai radikal bebas, yang dibandingkan dengan kemampuan atau kapasitas asam askorbat sebagai antioksidan.

$$
\begin{aligned}
& \text { Persen inhibisi }(\%)=\frac{A \cdot D P P H}{A \cdot A A_{\text {Em }}} \times 100 \%
\end{aligned}
$$

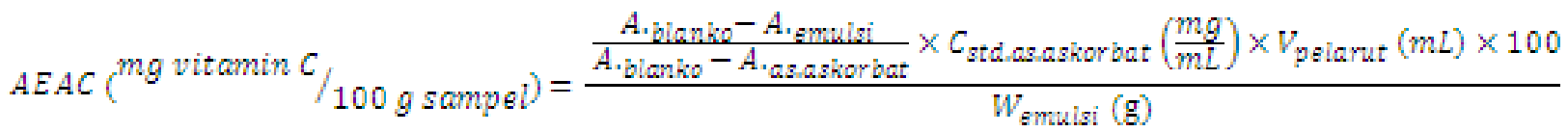

Keterangan:

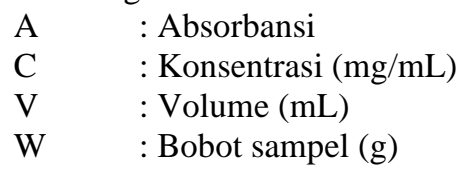

\section{Stabilitas Emulsi}

Stabilitas emulsi dilakukan dengan menggunakan sentrifugasi pada kecepatan 3000 rpm selama 10 menit, kemudian dilakukan pengamatan terhadap dispersi emulsi dan karakteristiknya (terjadinya pemisahan menjadi 2 atau 3 lapisan; terjadi sedimentasi, creaming, atau stabil) (Rinaldy, 2018).

\section{HASIL DAN PEMBAHASAN}

Metode permukaan respon (RSM) digunakan untuk menentukan formulasi atau variabel rasio konsentrasi VCO dan fikosianin yang sesuai untuk memprediksi respon $\mathrm{pH}$, viskositas, stabilitas emulsi dan kapasitas antioksidan. Produksi emulsi menggunakan fikosianin dan sirup sebagai fase air (kontinu) dengan VCO sebagai fase minyak, serta CMC sebagai zat pengemulsi. Variabel bebas yang digunakan adalah konsentrasi fikosianin dan VCO, sedangkan variabel tetap yaitu konsentrasi sirup dan CMC. Pengamatan stabilitas emulsi yang mengandung antioksidan berdasarkan konsentrasi dari fikosianin dan VCO karena masing-masing memiliki sifat fungsi antioksidan. Formulasi emulsi dapat dilihat pada Tabel 1.

Hasil respon permukaan dan plot kontur dari pengaruh variabel konsentrasi fikosianin dengan VCO terhadap respon $\mathrm{pH}$ dapat diamati pada Gambar 1. Grafik plot kontur (Gambar 1a) menunjukkan bahwa area berwarna kuning merupakan area $\mathrm{pH}$ terbaik, kondisi konsentrasi VCO dan fikosianin tertinggi. Area biru dalam plot kontur, merupakan area konsentrasi VCO tinggi 
dan konsentrasi fikosianin rendah, menghasilkan emulsi dengan $\mathrm{pH}$ asam. Hal tersebut disebabkan oleh $\mathrm{pH}$ asam yang dimiliki oleh VCO sebagai asam lemak jenuh (Silaban, 2015).

Interaksi permukaan antara komponenkomponen ini dapat dilihat lebih jelas pada grafik tiga dimensi yang ditunjukkan dalam Gambar 1b. Berdasarkan hasil analisis ragam, model relatif tidak signifikan karena nilai model F 2,16 dengan $p$-value > 0,05. Hasil tersebut menunjukkan variabel konsentrasi fikosianin dan VCO (pada rentang yang digunakan pada penelitian ini) tidak berpengaruh nyata terhadap respon $\mathrm{pH}$. Gambar 1 menunjukkan bahwa konsentrasi fikosianin dan VCO adalah antagonis untuk nilai $\mathrm{pH}$. Semakin tinggi konsentrasi fikosianin, nilai $\mathrm{pH}$ yang dihasilkan akan lebih rendah. Emulsi yang bersifat asam tersebut memiliki $\mathrm{pH}$ yang berkisar 4,065,77. Sifat asam emulsi diketahui dapat menghambat aktivitas mikroba, sehingga meningkatkan stabilitas produk (Khor et al., 2014). Untuk nilai $\mathrm{pH}$ tertinggi, dimiliki oleh formulasi F9 dengan konsentrasi fikosianin $150 \mathrm{~g}$ dan VCO $50 \mathrm{~g}$ dengan nilai 5,77 .
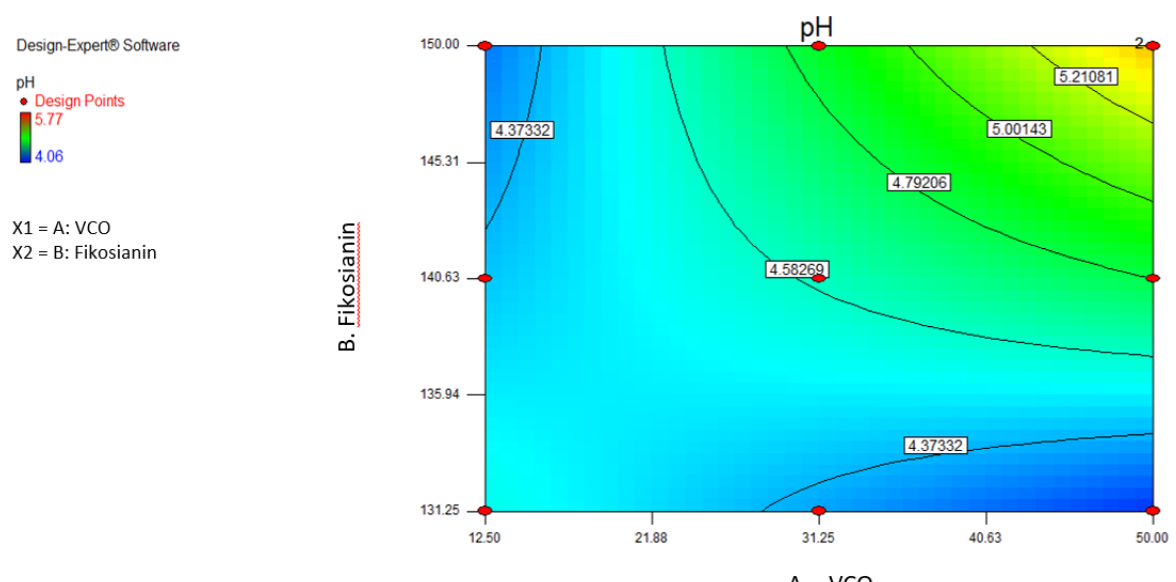

(a)
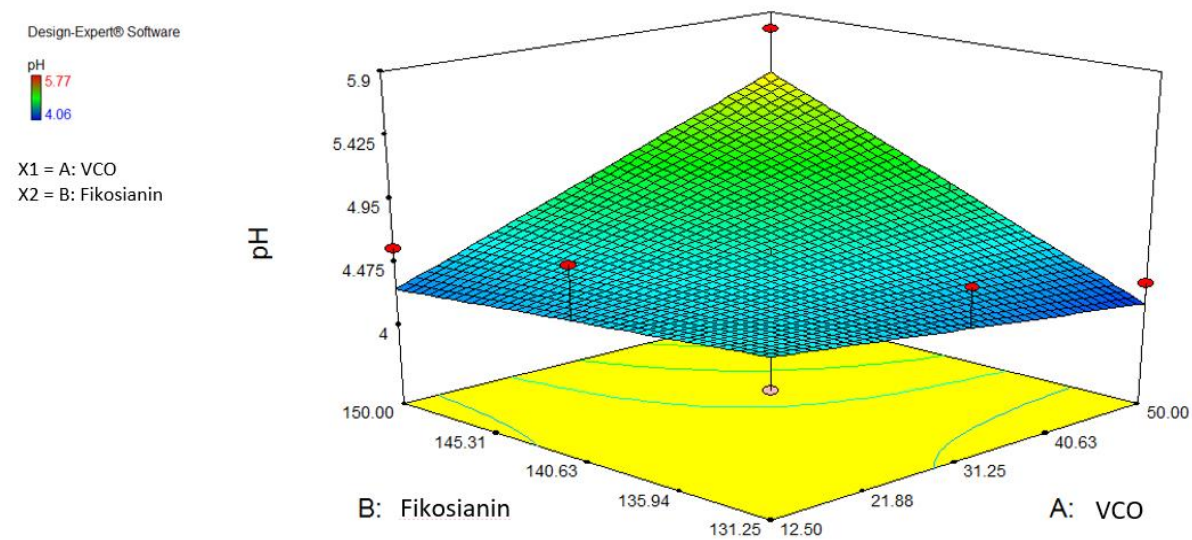

(b)

Gambar 1. Grafik kontur plot dari emulsi VCO-fikosianin terhadap nilai pH (a); Grafik tiga dimensi dari permukaan tanggap pada nilai $\mathrm{pH}(\mathrm{b})$

Stabilitas emulsi dapat dipengaruhi oleh beberapa faktor seperti konsentrasi fase kontinu, fase dispersi, penyimpanan suhu dan periode waktu. Dalam penelitian ini, kestabilan emulsi diamati selama 4 minggu (1 bulan) pada suhu 8-13 ${ }^{\circ} \mathrm{C}$. Tabel 3 menunjukkan hasil pengamatan yaitu penurunan kestabilan emulsi terjadi setelah masa penyimpanan 4 minggu. Formula 1, 3 dan 9 lebih cepat terpisah menjadi 2 lapisan (tidak stabil) dibandingkan dengan formula lainnya. Penelitian oleh Arancibia et al. (2016) juga telah memberikan hasil yang sama. Selama penyimpanan, terjadi tumbukan antara droplet secara perlahan yang menyebabkan penurunan tolakan antara droplet, kemudian menimbulkan agregasi yaitu berupa sedimentasi, creaming atau flokulasi (Arancibia et al. 2016). 
Tabel 3. Data pengamatan kestabilan emulsi

\begin{tabular}{clllllclcc}
\hline $\begin{array}{c}\text { Minggu } \\
\text { ke- }\end{array}$ & \multicolumn{1}{c}{$\mathbf{1}$} & $\mathbf{2}$ & $\mathbf{3}$ & $\mathbf{4}$ & $\mathbf{5}$ & $\mathbf{6}$ & $\mathbf{7}$ & $\mathbf{8}$ & $\mathbf{9}$ \\
\hline I & Homogen & Homogen & Homogen & Homogen & Homogen & Homogen & Homogen & Homogen & Homogen \\
\hline II & $\begin{array}{l}\text { Terpisah 2 } \\
\text { lapisan }\end{array}$ & Homogen & $\begin{array}{l}\text { Terpisah 2 } \\
\text { lapisan }\end{array}$ & Homogen & Homogen & Homogen & Homogen & Homogen & $\begin{array}{l}\text { Terpisah 2 } \\
\text { lapisan }\end{array}$ \\
\hline III & $\begin{array}{l}\text { Terpisah 2 } \\
\text { lapisan }\end{array}$ & Homogen & $\begin{array}{l}\text { Terpisah 2 } \\
\text { lapisan }\end{array}$ & Homogen & Homogen & Homogen & Homogen & Homogen & $\begin{array}{l}\text { Terpisah 2 } \\
\text { lapisan }\end{array}$ \\
\hline IV & $\begin{array}{l}\text { Terpisah 2 } \\
\text { lapisan }\end{array}$ & $\begin{array}{l}\text { Terpisah 2 } \\
\text { lapisan }\end{array}$ & $\begin{array}{l}\text { Terpisah 2 } \\
\text { lapisan }\end{array}$ & $\begin{array}{l}\text { Terpisah 2 } \\
\text { lapisan }\end{array}$ & $\begin{array}{l}\text { Terpisah 2 } \\
\text { lapisan }\end{array}$ & $\begin{array}{l}\text { Terpisah 2 } \\
\text { lapisan }\end{array}$ & $\begin{array}{l}\text { Terpisah 2 } \\
\text { lapisan }\end{array}$ & $\begin{array}{l}\text { Terpisah 2 } \\
\text { lapisan }\end{array}$ & $\begin{array}{l}\text { Terpisah 2 } \\
\text { lapisan }\end{array}$ \\
\hline
\end{tabular}

Hasil respon permukaan dan plot kontur dari pengaruh variabel konsentrasi fikosianin dengan VCO terhadap respon stabilitas emulsi ditunjukkan pada Gambar 2. Warna berbeda pada grafik plot kontur (Gambar 2a) menunjukkan nilai stabilitas emulsi. Warna biru menunjukkan nilai respon stabilitas terendah, yaitu $6,05 \mathrm{~cm}$. Warna biru muda menunjukkan respons stabilitas tertinggi, yaitu $0,35 \mathrm{~cm}$. Garis-garis yang terdiri dari titiktitik pada grafik plot kontur menunjukkan kombinasi kedua komponen dengan jumlah berbeda yang menghasilkan respon stabilitas yang sama. Interaksi antara komponen-komponen ini terhadap respon stabilitas emulsi dapat dilihat lebih jelas pada grafik tiga dimensi yang ditunjukkan pada Gambar 2b.

Hasil analisis ragam menunjukkan nilai model $\mathrm{F}$ adalah 0,9678 dengan $p$-value $>0,05$. Hal tersebut menunjukkan variabel konsentrasi fikosianin dan VCO (pada rentang yang digunakan
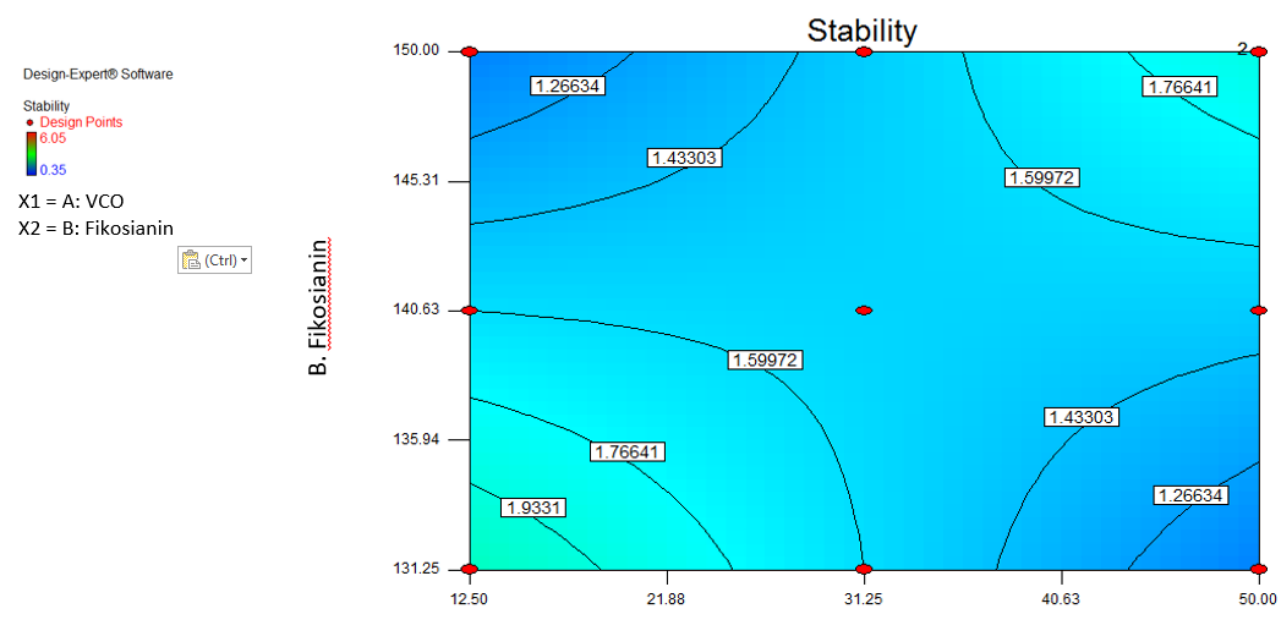

B. VCO

(a)
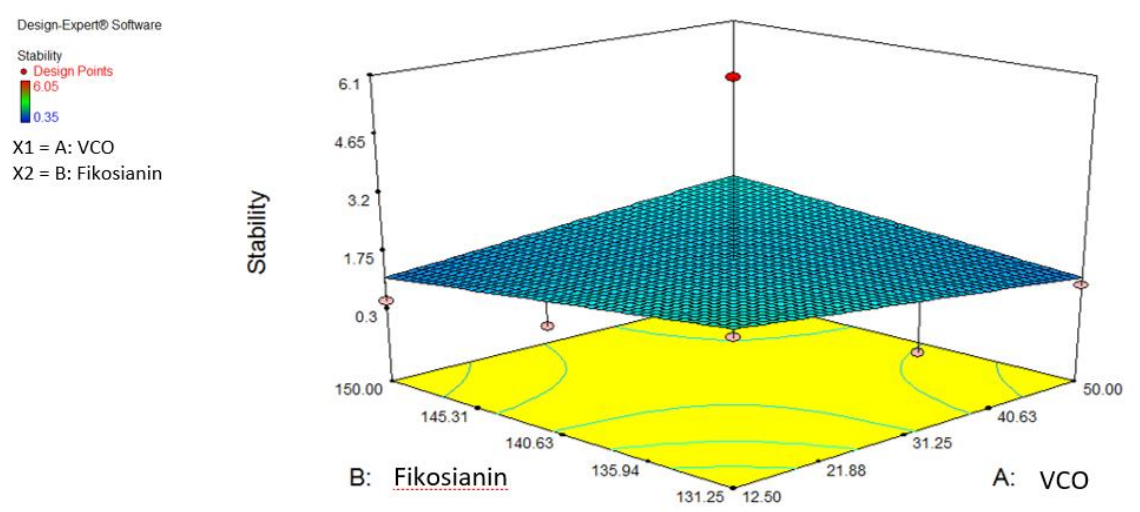

(b)

Gambar 2. Grafik kontur plot dari emulsi VCO-fikosianin terhadap stabilitas emulsi (a); Grafik tiga dimensi dari permukaan tanggap pada stabilitas emulsi (b) 
pada penelitian ini) tidak berpengaruh secara signifikan terhadap respon stabilitas emulsi. Hasil interaksi menunjukkan bahwa konsentrasi fikosianin dan VCO adalah berbanding terbalik dengan nilai stabilitas. Semakin tinggi konsentrasi fikosianin, maka akan memberikan nilai stabilitas yang lebih rendah, hal ini selaras dengan hasil penelitian yang dilakukan oleh (Rinaldy, 2018).

Emulsi dinyatakan stabil jika tidak terpisah menjadi dua lapisan (Suraweera et al., 2014). Stabilitas emulsi pada penelitian ini berkisar antara $0,35 \mathrm{~cm}$ hingga $6,05 \mathrm{~cm}$. Dispersi tertinggi adalah pada formulasi F6, dengan konsentrasi fikosianin $140,63 \mathrm{~g}$ dan VCO 31,25 g. Emulsi terpisah menjadi tiga lapisan, lapisan pertama adalah fase minyak, yang kedua adalah emulsi dan yang ketiga adalah fase air. Emulsi yang paling stabil adalah pada formulasi $\mathrm{F} 4$, dengan konsentrasi fikosianin $131,25 \mathrm{~g}$ dan VCO 31,25 g. Emulsi hanya terpisah menjadi dua lapisan, dengan lapisan pertama adalah fase minyak $(0,35 \mathrm{~cm})$ dan lapisan kedua adalah emulsi. Uji stabilitas akselerasi menggunakan sentrifugasi dengan kecepatan tinggi bertujuan untuk memprediksi stabilitas berupa fase pemisahan jangka panjang dari emulsi, dengan gaya sentrifugal tersebut emulsi lebih cepat rusak dibandingkan dengan kondisi normal. Emulsi VCO dapat terjadi flokulasi maupun pemisahan karena pergerakan droplet dari densitas VCO yang rendah ke atas permukaan emulsi, karena fase air dalam hal ini fikosianin memiliki densitas atau kerapatan lebih tinggi (Suraweera et al., 2015). Fikosianin mampu menstabilkan emulsi minyak dalam air (Batista et al., 2006) karena merupakan hasil ekstraksi senyawa protein, dimana pada umumnya emulsi minyak dalam air pada makanan distabilkan menggunakan protein.

Salah satu faktor yang mempengaruhi stabilitas emulsi adalah viskositas emulsi. Produksi emulsi dilakukan dengan homogenizer bertekanan tinggi pada tekanan $30 \mathrm{MPa}$ selama 10 menit. Tekanan tinggi akan menyebabkan pembentukan molekul tinggi yang meningkatkan viskositas emulsi. Gambar 3 menunjukan grafik hasil respon permukaan dan plot kontur dari pengaruh variabel konsentrasi fikosianin dengan VCO terhadap respon viskositas. Gambar 3a menunjukkan kombinasi komponen yang mempengaruhi nilai viskositas emulsi. Warna yang berbeda pada grafik plot kontur menunjukkan nilai viskositas. Warna biru menunjukkan nilai viskositas terendah yaitu 20 cps. Warna kuning menunjukkan nilai viskositas tertinggi yaitu 113 cps. Viskositas tertinggi adalah pada formulasi $\mathrm{F} 4$ dengan konsentrasi fikosianin 131,25 g dan VCO 31,25 g. Hasil analisis ragam menunjukkan bahwa variabel konsentrasi fikosianin dan VCO (pada rentang yang digunakan pada penelitian ini) tidak berpengaruh secara signifikan terhadap respon viskositas. Hal ini karena viskositas dipengaruhi oleh beberapa faktor seperti konsentrasi dari zat pengemulsi CMC. Interaksi antara konsentrasi VCO dan fikosianin adalah sinergi dengan viskositas. Semakin tinggi konsentrasi VCO akan memberikan viskositas yang lebih tinggi, hasil sesuai dengan penelitian yang dilakukan oleh (Suraweera et al., 2014). Kandungan minyak yang tinggi dan viskositas yang tinggi dapat menimbulkan creaming pada emulsi.
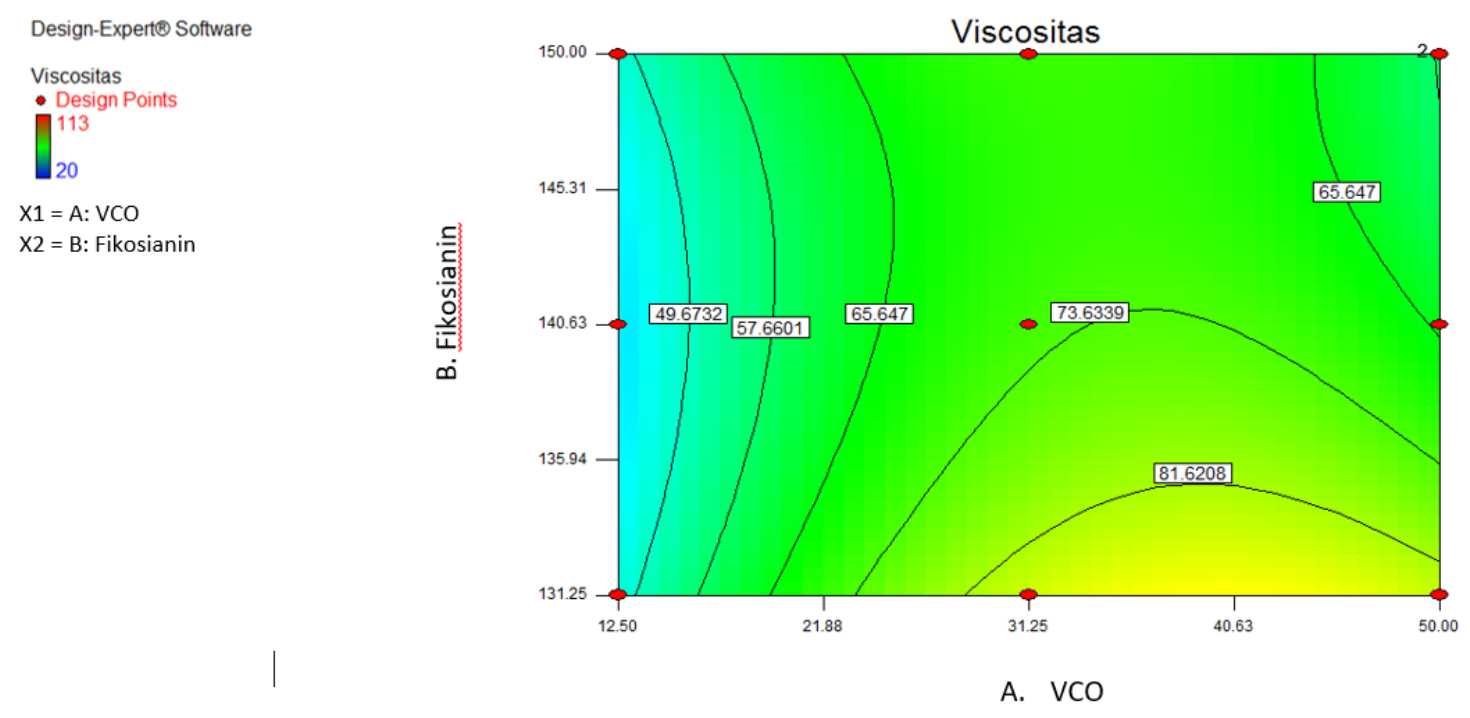

Gambar 3a. Grafik kontur plot emulsi VCO-fikosianin terhadap viskositas 

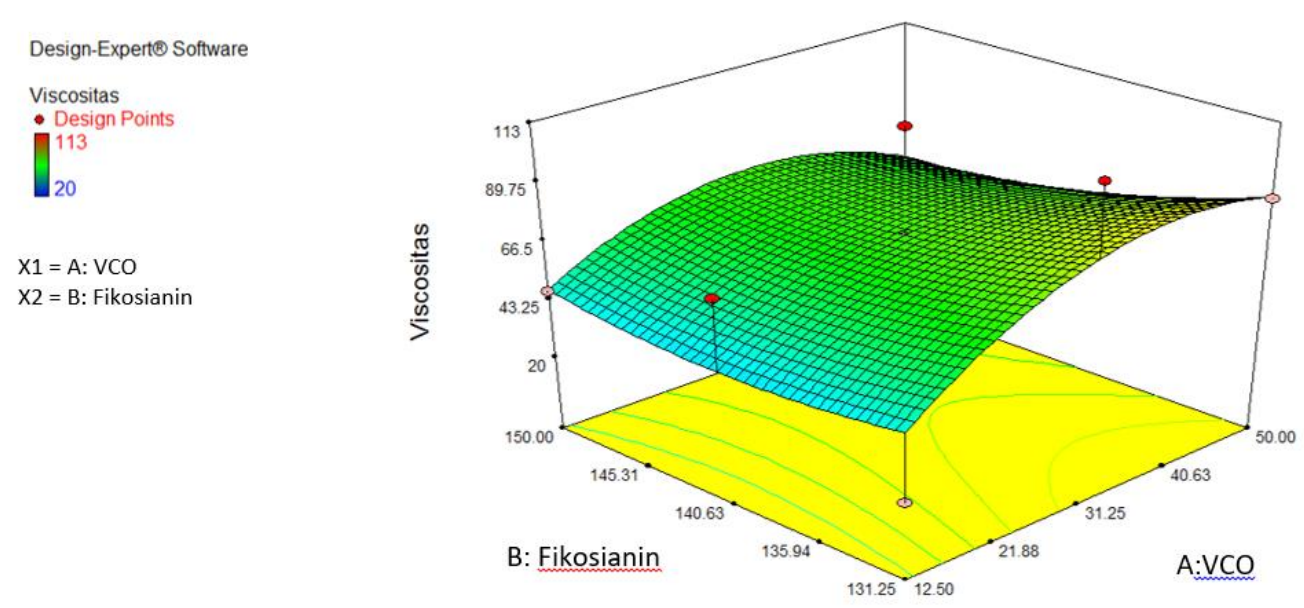

Gambar 3.b Grafik tiga dimensi permukaan tanggap pada viskositas

Hasil respon permukaan dan plot kontur dari pengaruh variabel konsentrasi fikosianin dengan VCO terhadap respon kapasitas antioksidan dapat diamati pada Gambar 4. Grafik kontur plot pada Gambar 4a menunjukkan bagaimana kombinasi komponen mempengaruhi nilai antioksidan. Warna berbeda pada grafik kontur plot menunjukkan nilai antioksidan. Warna biru kehijauan menunjukkan nilai antioksidan terendah, yaitu $0,03 \mathrm{mg}$ vitamin $\mathrm{C} / \mathrm{g}$. Warna hijau kekuningan menunjukkan nilai antioksidan yang sama. Antioksidan tertinggi adalah $0,13 \mathrm{mg}$ vitamin $\mathrm{C} / \mathrm{g}$. Bentuk permukaan interaksi antara komponen-komponen ini dapat dilihat lebih jelas pada grafik tiga dimensi yang ditunjukkan pada Gambar 4b. Berdasarkan analisis ragam, nilai model $\mathrm{F}$ yaitu 0,553 dan p-value > 0,05 menunjukkan variabel konsentrasi fikosianin dan VCO (pada rentang yang digunakan pada penelitian ini) tidak berpengaruh secara signifikan terhadap respon kapasitas antioksidan.
Hasil interaksi menunjukkan bahwa konsentrasi VCO dan fikosianin adalah berlawanan untuk nilai antioksidan. Semakin rendah konsentrasi VCO, maka semakin rendah nilai antioksidannya. Sebaliknya, semakin tinggi konsentrasi fikosianin, nilai antioksidan yang dihasilkan akan lebih tinggi. Nilai antioksidan terendah terdapat pada formulasi F3 yaitu konsentrasi VCO 12,50 g dan fikosianin $150 \mathrm{~g}$. Meskipun memiliki kadar fikosianin tinggi, namun nilai antioksidan rendah. Hal tersebut disebabkan oleh kadar VCO yang rendah, sehingga VCO tidak mampu melindungi fikosianin dari proses oksidasi. VCO memiliki kemampuan untuk menstabilkan dan menghambat laju kerusakan dari antioksidan yang setara dengan vitamin C (Suhendra et al., 2014). Emulsi minyak dalam air mempunyai daya hambat dalam kerusakan antioksidan yang lebih baik daripada emulsi air dalam minyak.
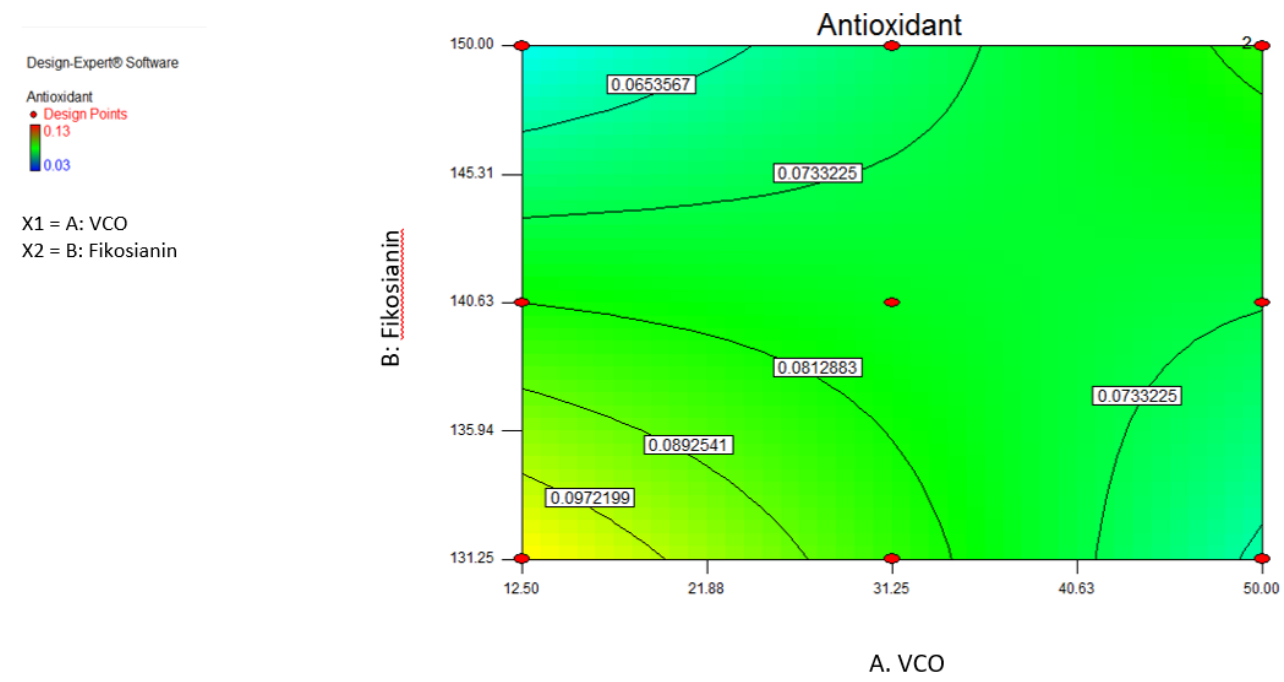

Gambar 4.a Grafik kontur plot emulsi VCO-fikosianin terhadap kapasitas antioksidan 

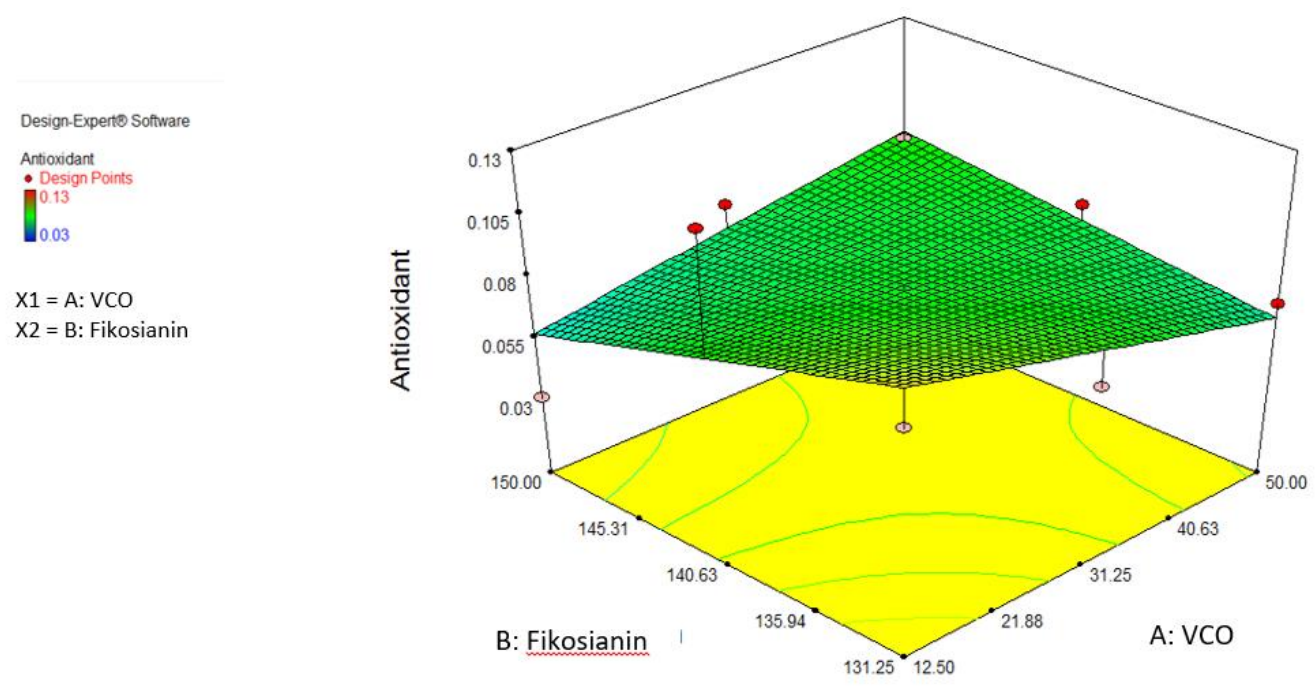

Gambar 4.b Grafik tiga dimensi permukaan tanggap pada kapasitas antioksidan

Grafik plot kontur pada Gambar 5a menunjukkan kombinasi komponen mempengaruhi aktivitas antioksidan sebagai nilai aktivitas antiokisdan $\mathrm{IC}_{50}$. Nilai $\mathrm{IC}_{50}$ yang rendah menunjukkan semakin tinggi aktivitas antioksidan (Agustina et al., 2019). Warna berbeda pada grafik plot kontur menunjukkan nilai aktivitas antioksidan sebagai $\mathrm{IC}_{50}$. Warna biru kehijauan menunjukkan aktivitas antioksidan tertinggi sebagai $\mathrm{IC}_{50}$, yaitu $398 \mathrm{mg} / \mathrm{ml}$. Warna kuning menunjukkan aktivitas antioksidan terendah sebagai $\mathrm{IC}_{50}$, yaitu $1410,68 \mathrm{mg} / \mathrm{ml}$.

Aktivitas antioksidan tertinggi sebagai $\mathrm{IC}_{50}$ adalah pada formulasi $\mathrm{F} 1$ dengan konsentrasi fikosianin 140,63 g dan VCO 12,5 g, sedangkan aktivitas antioksidan terendah pada formulasi F2 yaitu konsentrasi fikosianin 131,25 g dan VCO 50 g. Hasil interaksi antara konsentrasi VCO dan fikosianin menunjukkan saling berlawanan dengan aktivitas antioksidan sebagai $\mathrm{IC}_{50}$. Semakin tinggi konsentrasi VCO dan semakin rendah fikosianin, maka akan memberikan aktivitas antioksidan yang lebih rendah. Hal tersebut menunjukkan bahwa fikosianin merupakan sumber antioksidan. VCO sebagai fase minyak dapat menghambat kerusakan antioksidan (Suhendra et al., 2014), sehingga dapat meningkatkan aktivitas antioksidan. Hasil analisis ragam pada RSM menunjukkan bahwa nilai $\mathrm{F}$ model sebesar 0,2681 dan p-value >0,05 menunjukkan bahwa variabel konsentrasi fikosianin dan VCO (pada rentang yang digunakan pada penelitian ini) tidak berpengaruh terhadap respon aktivitas antioksidan atau $\mathrm{IC}_{50}$.
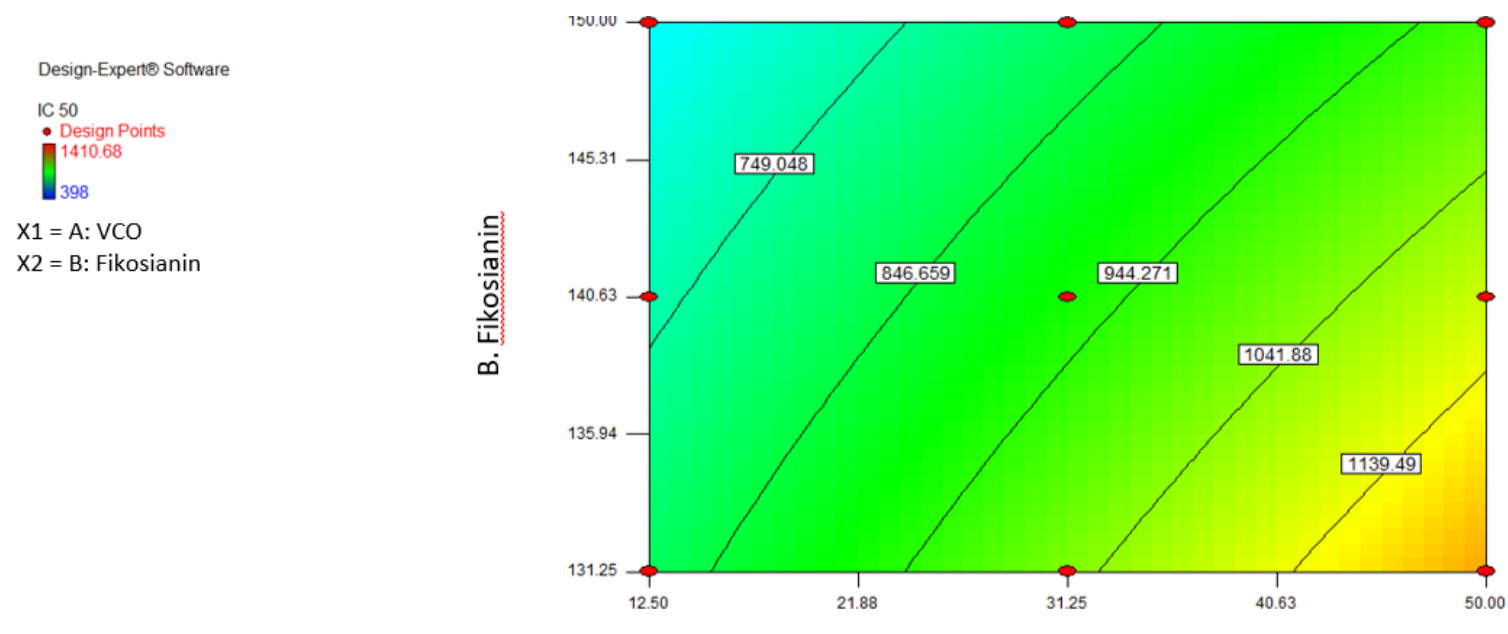

A. VCO

Gambar 5.a Grafik kontur plot emulsi VCO-fikosianin terhadap aktivitas antioksidan atau IC $_{50}$ 


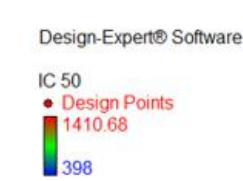

$\mathrm{X} 1=\mathrm{A}: \mathrm{VCO}$

$\mathrm{X} 2$ = B: Fikosianin

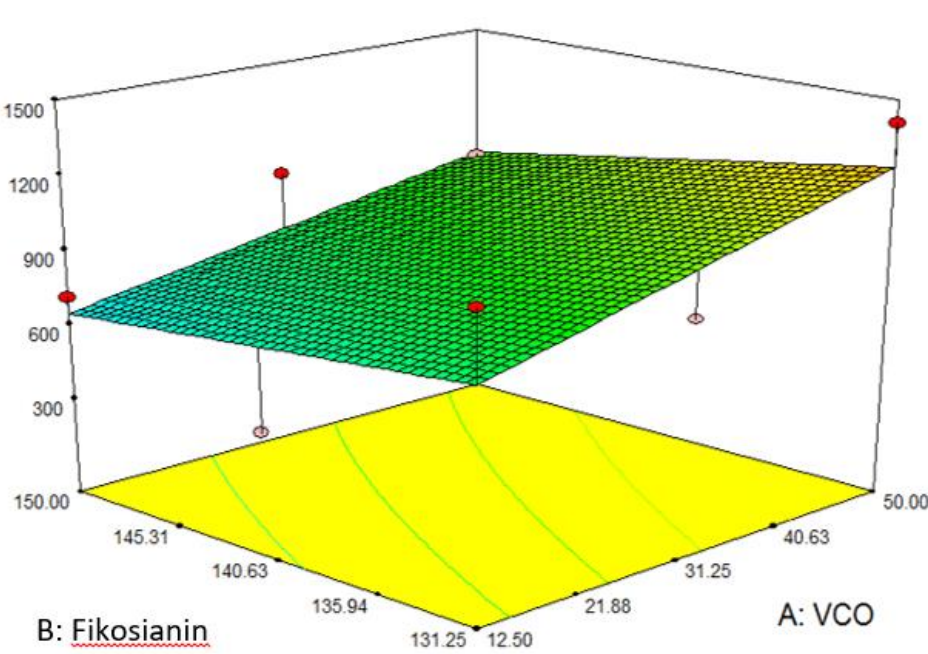

(b)

Gambar 5.b Grafik tiga dimensi permukaan tanggap pada aktivitas antioksidan atau $\mathrm{IC}_{50}(\mathrm{~b})$

Berdasarkan analisis ragam, variabel konsentrasi fikosianin dan VCO yang digunakan pada penelitian ini, tidak berpengaruh signifikan terhadap variable $\mathrm{pH}$, kestabilan emulsi, viskositas dan kapasitas antioksidan dari emulsi. Hal tersebut dikarenakan kapasitas antioksidan tidak hanya dipengaruhi oleh konsentrasi fikosianin sebagai sumber antioksidan namun juga dipengaruhi oleh kestabilan emulsi. Kestabilan emulsi akan menurunkan resiko teroksidasinya antioksidan fikosianin saat proses homogenisasi bertekanan tinggi. Hasil formulasi emulsi didapatkan bahwa formula terbaik adalah menggunakan fikosianin sebesar 131,25 g dan VCO 31,25 g dengan kadar antioksidan sebesar 0,07 mg vitamin $\mathrm{C} / \mathrm{g}, \mathrm{pH} 4,64$ dengan viskositas sebesar $113 \mathrm{cps}$.

\section{KESIMPULAN}

Proses formulasi emulsi fikosianin sebagai antioksidan dengan VCO menggunakan zat pengemulsi CMC dengan homogenisasi bertekanan tinggi (30 $\mathrm{MPa}, 10$ menit) memiliki formulasi terbaik pada konsentrasi fikosianin 131,25 dan VCO 31,25. Karakteristik emulsi pada formulasi tersebut adalah $\mathrm{pH} 4,64$; stabilitas emulsi paling baik yaitu terdispersi $0,35 \mathrm{~cm}$, viskositas $113 \mathrm{cps}$, kadar antioksidan $0,07 \mathrm{mg}$ vitamin $\mathrm{C} / \mathrm{g}$ dan aktivitas antioksidan $\mathrm{IC}_{50} 838,80 \mathrm{mg} / \mathrm{ml}$ Formula emulsi tersebut lebih stabil dibandingkan dengan formula lainnya. Emulsi dapat diterapkan pada industri kosmetik, farmasi dan makanan.

\section{DAFTAR PUSTAKA}

Agustina, S., Aidha, N., \& Oktarina, E. (2018). Ekstraksi antioksidan spirulina sp. dengan menggunakan metode ultrasonikasi dan aplikasinya untuk krim kosmetik. Jurnal Kimia Dan Kemasan, 40(2), 105-116.

Agustina, S., Aidha, N., \& Oktarina, E. (2019). Effect of maltodextrin concentration on the characteristic of phycocyanin powder as a functional food. AIP Conference Proceedings, 2175(November). https://doi.org/10.1063/1.5134614

Anwar, C., \& Salima, R. (2016). Perubahan rendemen dan mutu virgin coconut oil (vco) pada berbagai kecepatan putar dan lama waktu sentrifugasi. Jurnal Teknotan, 10(2), 51-60.

Arancibia, C., Navarro-Lisboa, R., Zúñiga, R. N., \& Matiacevich, S. (2016). Application of CMC as thickener on nanoemulsions based on olive oil: Physical properties and stability. International Journal of Polymer Science, 2016. https://doi.org/10.1155/2016/6280581

Batista, A. P., Raymundo, A., Sousa, I., \& Empis, J. (2006). Rheological characterization of coloured oil-in-water food emulsions with lutein and phycocyanin added to the oil and aqueous phases. Food Hydrocolloids, 20(1), 44-52. https://doi.org/10.1016/j.foodhyd.2005.02.009

Chaiklahan, R., Chirasuwan, N., \& Bunnag, B. (2012). Stability of phycocyanin extracted from Spirulina sp.: Influence of temperature, $\mathrm{pH}$ and preservatives. Process Biochemistry, 47(4), 659664.

https://doi.org/10.1016/j.procbio.2012.01.010

Dejsungkranont, M., Chen, H. H., \& Sirisansaneeyakul, S. (2017). Enhancement of antioxidant activity of C-phycocyanin of Spirulina powder treated with supercritical fluid carbon dioxide. Agriculture 
and Natural Resources, 51(5), 347-354. https://doi.org/10.1016/j.anres.2017.12.001

Eriksen, N. T. (2008). Production of phycocyanin - A pigment with applications in biology, biotechnology, foods and medicine. Applied Microbiology and Biotechnology, 80(1), 1-14. https://doi.org/10.1007/s00253-008-1542-y

Furuki, T., Maeda, S., Imajo, S., Hiroi, T., Amaya, T., Hirokawa, T., Ito, K., \& Nozawa, H. (2003). Rapid and selective extraction of phycocyanin from. Journal of Applied Phycology, 15(1979), 319-324. A: 1025118516888

Hemalatha, S., Sundaram, R. M., Shaheedha, S. M., \& Reddy, K. B. (2015). Formulation and evaluation characterization of nanoemulsion containing arthrospira platensis (spirulina) extract. International Journal of Phytopharmacology, 6(4), 255-260.

Juttulapa, M., Piriyaprasarth, S., Takeuchi, H., \& Sriamornsak, P. (2017). Effect of high-pressure homogenization on stability of emulsions containing zein and pectin. Asian Journal of Pharmaceutical Sciences, 12(1), 21-27. https://doi.org/10.1016/j.ajps.2016.09.004

Khor, Y. P., Koh, S. P., Long, K., Long, S., Ahmad, S. Z. S., \& Tan, C. P. (2014). A comparative study of the physicochemical properties of a virgin coconut oil emulsion and commercial food supplement emulsions. Molecules, 19(7), 91879202.

https://doi.org/10.3390/molecules19079187

Kuhn, K. R., \& Cunha, R. L. (2012). Flaxseed oil Whey protein isolate emulsions: Effect of high pressure homogenization. Journal of Food Engineering, 111(2), 449-457. https://doi.org/10.1016/j.jfoodeng.2012.01.016

Mason, S. L., \& Bonnet, M. (2011). Multiple emulsions for colorants EP2635137A1 (Patent No. EP2635137A1).

McClements, D. J. (2005). Food emulsion. In $C R C$ Press (2nd ed., Issue 2nd). CRC Pres. https://doi.org/10.1017/CBO9781107415324.004

Nevin, K. G., \& Rajamohan, T. (2004). Beneficial effects of virgin coconut oil on lipid parameters and in vitro LDL oxidation. Clinical Biochemistry, 37(9), 830-835. https://doi.org/10.1016/j.clinbiochem.2004.04.01 0

Nurhayati, N., \& Budiyanto, B. (2016). Stability and Preference of Red Palm Oil Emulsion Prepared With Various Concentration of Tween 80. Jurnal
Agroindustri, $\quad 6(2), \quad 80-87$. https://doi.org/10.31186/j.agroind.6.2.80-87

Rinaldy, R. (2018). Optimasi Formula Emulsi Kombinasi Minyak Zaitun dan Ekstrak Buah Alpukat Menggunakan Metode Factorial Design. Universitas Muhammadiyah Surakarta.

Silaban, R. V. (2015). Pembuatan dan Evaluasi Secara In Vitro Emulsi Virgin Coconut Oil (VCO) Menggunakan Emulgator Tween 80 dan Gom Arab. In Skripsi. Universitas Sumatera Utara.

Silva, H. D., Cerqueira, M. A., \& Vicente, A. A. (2012). Nanoemulsions for food applications: development and characterization. Food and Bioprocess Technology, 5(3), 854-867. https://doi.org/10.1007/s11947-011-0683-7

Suhendra, L., Raharjo, S., Hastuti, P., \& Hidayat, C. (2014). Fucoxanthin microemulsion stability and its effectiveness in inhibiting photooxidation of vitamin c in beverage model. Agritech, 34(2), $138-145$.

Suraweera, R. K., Pasansi, H. G. P., Herath, H. M. D. R., Wickramaratne, D. B. M., Sudeshika, S. H. T., Niyangoda, D., \& Sakeena, M. H. F. (2014). Formulation and stability evaluation of ketoprofen loaded virgin coconut oil based creamy emulsion. International Journal of Pharmacy and Pharmaceutical Sciences, 6(8), 249-254.

Suraweera, R. K., Pasansi, H. G. P., \& Sakeena, M. H. F. (2015). Assessing the characterizations of ketoprofen loaded and unloaded virgin coconut oil based creamy nanoemulsion. Asian Journal of Pharmaceutical and Clinical Research, 8(1), 275-279.

Teuling, E., Schrama, J. W., Gruppen, H., \& Wierenga, P. A. (2019). Characterizing emulsion properties of microalgal and cyanobacterial protein isolates. Algal Research, 39(February). https://doi.org/10.1016/j.algal.2019.101471

Villarino, B. J., Dy, L. M., \& Lizada, M. C. C. (2007). Descriptive sensory evaluation of virgin coconut oil and refined, bleached and deodorized coconut oil. LWT - Food Science and Technology, 40(2), 193-199. https://doi.org/10.1016/j.lwt.2005.11.007

Wang, B., Cai, T., Liu, Q., Whitney, J. C. C., Du, M., Ma, Q., Zhang, R., Yang, L., Cole, S. P. C., \& Cai, Y. (2018). Preparation and evaluation of spirulina polysaccharide nanoemulsions. International Journal of Molecular Medicine, 42(3), $1273-1282$. https://doi.org/10.3892/ijmm.2018.3717 